(c) American Dairy Science Association, 2005.

\title{
Antioxidative Activity of Lactobacilli Measured by Oxygen Radical Absorbance Capacity*
}

\author{
J. A. O. Saide† and S. E. Gilliland \\ Department of Animal Science and Food and Agricultural Products Center, \\ Oklahoma State University, Stillwater 74078
}

\begin{abstract}
The reducing ability and antioxidative activity of some species of Lactobacillus were compared under in vitro conditions. Cultures of Lactobacillus delbrueckii ssp. lactis, Lactobacillus delbrueckii ssp. bulgaricus, Lactobacillus acidophilus, and Lactobacillus casei were grown at $37^{\circ} \mathrm{C}$ in de Man, Rogosa, Sharpe (MRS) broth supplemented with $0.5 \%$ 2,3,5 triphenyl tetrazolium chloride (TTC) to evaluate reducing activity. Reduced TTC was extracted from the cultures with acetone, and the intensity of the red color measured colorimetrically at $485 \mathrm{~nm}$ was an indication of reducing activity. The lactobacilli varied significantly in relative ability to reduce TTC when grown in MRS broth for $15 \mathrm{~h}$. The relative amounts of growth as indicated by $\mathrm{pH}$ values at $18 \mathrm{~h}$ appeared to influence the amount of reduction. Antioxidative activity was evaluated by the ability of the whole cells or the cell-free extracts from cultures to protect a protein from being attacked by free radicals. These analyses were performed using the oxygen radical absorbance capacity method. All cultures tested exhibited some degree of antioxidative activity. Among the treatments, the cell-free extracts from cells grown in MRS broth exhibited significantly higher values than did whole cells. There was no apparent relationship between the reducing and antioxidative activities of the cultures evaluated. The results from this study show that these cultures can provide a source of dietary antioxidants. Furthermore, selection of cultures that produce antioxidants as starters could provide yet another health or nutritional benefit from cultured or culturecontaining dairy products.
\end{abstract}

(Key words: antioxidative, reductase, lactobacilli)

Abbreviation key: AAPH = 2,2'-azobis(2-amidinopropane)dihydrochloride, MRS = de Man, Rogosa, Sharpe,

\footnotetext{
Received June 16, 2004.

Accepted December 4, 2004.

Corresponding author: S. E. Gilliland; e-mail: seg@okstate.edu.

*Approved for publication by the Director, Oklahoma Agricultural Experiment Station. This project was supported under Project H2293 and Sitlington Endowment Funds.

$\dagger$ Current address: R. Antonio Jose de Almeida 169 R/C esq., B.R.U., Maputo, Mozambique.
}

ORAC = oxygen radical absorbance capacity, ROS = reactive oxygen species, $\mathbf{T T C}=2,3,5$ triphenyl tetrazolium chloride.

\section{INTRODUCTION}

The interest in reactive oxygen species (ROS) in biology and medicine is evident because of their strong relationship with phenomena such as aging and disease processes (Cao et al., 1995). The concept of ROS comprises not only oxygen-centered radicals such as $\mathrm{O}_{2}^{--}$ and $\mathrm{OH}$, but also nonradical derivatives of oxygen such as $\mathrm{H}_{2} \mathrm{O}_{2}$ and hypochlorous acid. It is well known that free radicals and other ROS are continuously being produced in living organisms. As a consequence, defense mechanisms have evolved to deactivate these free radicals and repair the damage caused by their reactivity (Halliwell and Chirico, 1993). However, these systems are not always sufficiently active to disarm the totality of metabolically produced or exogenous free radicals.

Most lactic acid bacteria have systems to cope with oxygen radicals. According to Stecchini et al. (2000) the most common systems are superoxide dismutase and high internal concentrations of $\mathrm{Mn}^{2+}$. Knauf et al. (1992) also reported that some species of lactobacilli produced a heme-dependent catalase, which can degrade $\mathrm{H}_{2} \mathrm{O}_{2}$ at a very high rate, blocking the formation of peroxyl radicals. The ability of lactic acid bacteria to create low oxidation-reduction potential needed for their optimum growth probably is related to some of these systems. Reducing activity can be measured by the ability of the organisms to reduce 2, 3, 5-triphenyl tetrazolium chloride (TTC) (Laxminarayana and Iya, 1954).

Free radical scavenger properties of starter cultures would be useful in the food manufacturing industry. They could beneficially affect the consumer by providing another dietary source of antioxidants (Ouwehand and Salminen, 1998) or by providing probiotic bacteria with the potential of producing antioxidants during growth in the intestinal tract. Some species of lactobacilli and bifidobacteria have been reported to produce antioxidative activity (Zaizu et al., 1993; Korpela et al., 1997; Lin and Yen, 1999c; Kullisar et al., 2002). The 
intensity of antioxidative activity varied among cultures in each study. Most of these studies based the results on evaluation of cell-free extracts of the bacteria.

There are many methods to assess free radical scavenging ability, such as Trolox-equivalent antioxidant capacity and ferric-reducing ability (Cao and Prior, 1998). Most of these methods assess one of the 2 components of the antioxidative process, measuring time to reach a fixed degree of inhibition or the extent of inhibition at a fixed time (Cao et al., 1995).

The oxygen radical absorbance capacity (ORAC) assay is, to date, the only method combining both variables (Wang et al., 1996; Cao and Prior, 1998; Cao et al., 1998). The ORAC assay is based on the protection by the antioxidant of a target compound exposed to an oxidant. It is measured by the change in fluorescence caused by oxidation of the target compound. The assay permits measurement of the total antioxidant capacity of the sample being tested. This is basically a process whereby the reaction between a ROS, such as hydroxyl or peroxyl radicals, and a target molecule, such as lowdensity lipoprotein or $\beta$-phycoerythrin, can be monitored (Handelman et al., 1999). In the case of $\beta$-phycoerythrin, the structural change is reflected in the decrease of fluorescence.

The objective of this study was to compare the antioxidative activity of various species of lactobacilli used as yogurt starter cultures or as probiotic bacteria. A second objective was to determine whether reducing activity, based on the reduction of TTC could be used to predict relative antioxidative activity of these organisms.

\section{MATERIALS AND METHODS}

\section{Source and Maintenance of Cultures}

The cultures used in this study (Lactobacillus acidophilus, Lactobacillus delbrueckii ssp. lactis, Lactobacillus delbrueckii ssp. bulgaricus, and Lactobacillus casei) were obtained from the stock culture collection of the Food Microbiology Laboratory in the Food and Agricultural Products Research and Technology Center at Oklahoma State University. Cultures were maintained by subculture in de Man, Rogosa, Sharpe (MRS) broth (Difco Laboratories, Detroit, MI) using 1\% inocula and incubation for $18 \mathrm{~h}$ at $37^{\circ} \mathrm{C}$. Between uses, cultures were stored at $5^{\circ} \mathrm{C}$. To make freshly prepared cultures for experiments, immediately before use, they were subcultured 3 times on successive days in MRS broth.

\section{Plate Counts}

The total numbers of lactobacilli in the cultures were determined using the pour plate method (with overlay) on MRS agar. The samples were diluted in $0.1 \%$ peptone
(Sigma Chemical Co., St. Louis, MO) dilution blanks $(99 \mathrm{~mL}$ ) containing $0.01 \%$ silicone antifoamer (Sigma Chemical Co.). Duplicate plates of the appropriate dilutions were prepared and incubated at $37^{\circ} \mathrm{C}$ for $48 \mathrm{~h}$. The colonies were counted with the aid of a Quebec colony counter (American Optical Co., Buffalo, NY), and the colony-forming units per milliliter were determined.

\section{Screening Cultures for Reducing Activity}

A stock solution of TTC (Sigma Chemical Co.) was prepared by dissolving $50 \mathrm{mg}$ in $10 \mathrm{~mL}$ of distilled water and passing it through a sterile membrane filter $(0.45-\mu \mathrm{m}$ pore diameter; Gelman Laboratory, Ann Arbor, MI) into a sterile tube. The solution was prepared fresh daily and kept in the dark by wrapping the tube in aluminum foil.

For the screening of reducing activity, tubes containing 9-mL volumes of sterile modified MRS broth (without beef extract; as it interfered with the assay) supplemented with $1 \mathrm{~mL}$ of $0.5 \%$ (wt/vol) TTC (added just before use) were inoculated with $0.1 \mathrm{~mL}$ of freshly prepared cultures and incubated for $18 \mathrm{~h}$ at $37^{\circ} \mathrm{C}$. After the incubation, $0.8-\mathrm{mL}$ aliquots were removed from each tube and dispensed into $1.8-\mathrm{mL}$ microcentrifuge tubes along with an equal volume of acetone (Pharmaco, Brookfield, CT) and shaken vigorously for $30 \mathrm{~s}$. The microcentrifuge tubes were placed in an ice-water bath for $3 \mathrm{~h}$ to allow maximum extraction of the formazan. Then, the tubes were centrifuged at $12,000 \times g$ for 10 min. One milliliter of the supernatant in each tube was collected with a $1-\mathrm{mL}$ pipette and dispensed into a $1-\mathrm{mL}$ cuvette. Then, the absorbance at $485 \mathrm{~nm}$ was read using a spectrophotometer (Spectronic 21D; Milton Roy Co., Rochester, NY) against a blank of deionized water. The remaining portions of the initial $9 \mathrm{~mL}$ of cultures were checked for $\mathrm{pH}$.

\section{Antioxidative Activity of Broth Cultures}

Freshly prepared cultures were used to inoculate (1\%) 50-mL volumes of sterile MRS broth followed by incubation for $18 \mathrm{~h}$ at $37^{\circ} \mathrm{C}$. After incubation, the cultures were centrifuged at $12,000 \times g$ for $10 \mathrm{~min}$ at $4^{\circ} \mathrm{C}$. The supernatant was discarded, and the pellet was washed by resuspending it in $50 \mathrm{~mL}$ of deionized water and centrifuging it again under the same conditions. This wash procedure was repeated 3 times. Finally, each washed pellet was resuspended in $50 \mathrm{~mL}$ of 0.2 $M$ potassium phosphate buffer (pH 7.0) and aseptically dispensed (in $25-\mathrm{mL}$ aliquots) into 2 sterile vials to prepare the samples corresponding to whole cells and cell-free extracts.

The suspension of whole cells was incubated at $37^{\circ} \mathrm{C}$ for $30 \mathrm{~min}$. The cell-free extract was obtained by son- 
icating the cells suspended in buffer at setting 4 (Sonic Dismembranator; Heat Systems Ultrasonics, New York, NY) for $5 \mathrm{~min}$. To avoid temperature damage during sonication, tubes were maintained in an icewater mixture.

At the end of the incubation period, the whole cells and the sonicated cells were centrifuged as previously described for removal of cells or cell debris, and the supernatants were collected for evaluation of antioxidative activity. Buffer (0.2 $M$ phosphate buffer; $\mathrm{pH}$ 7.0) solution without cells was used as the control.

\section{Measuring the Antioxidative Activity}

Assay for antioxidative activity. The antioxidative activity of the samples from the cultures was measured according to the method described by Cao et al. (1995). For convenience, the protocol is described here. The stock solution of $\beta$-phycoerythrin (Sigma Chemical Co.) was prepared by dissolving $1 \mathrm{mg}$ into $5.6 \mathrm{~mL}$ of phosphate buffer $(0.2 M$; pH 7.0). This stock solution was kept under refrigeration. The working solution was made by mixing $300 \mu \mathrm{L}$ of the stock solution with 13.4 $\mathrm{mL}$ of phosphate buffer just before use. A solution of 2,2'-azobis(2-amidinopropane)dihydrochloride (AAPH; Waco Chemical USA, Richmond, VA) was prepared fresh immediately before running the assay. For this, $60 \mathrm{mg}$ of AAPH was weighed and dissolved in 5 $\mathrm{mL}$ of phosphate buffer. A solution of 6-hydroxy-2,5,7,8tetramethylchroman-2-carboxylic acid (Trolox; Aldrich Chem, Inc., Milwaukee, WI) was prepared by dissolving $5 \mathrm{mg}$ of the substance in $200 \mathrm{~mL}$ of $0.2 \mathrm{M}$ phosphate buffer as a stock solution $(100 \mu M)$. To obtain a working solution, $1 \mathrm{~mL}$ of the stock solution was mixed with 9 $\mathrm{mL}$ of phosphate buffer. The stock solution was stored at $2^{\circ} \mathrm{C}$. Phosphate buffer was prepared by mixing 0.75 $M$ solutions of $\mathrm{K}_{2} \mathrm{HPO}_{4}$ and $\mathrm{NaH}_{2} \mathrm{PO}_{4}$ in a 61.6:38.9 $\mathrm{vol} / \mathrm{vol}$ ratio. The mixture was then diluted 1:9 with distilled water, and the $\mathrm{pH}$ was adjusted to $\mathrm{pH} 7$. This working solution $(0.2 \mathrm{M})$ was stored at $2^{\circ} \mathrm{C}$.

In the assay, the substrate ( $\beta$-phycoerythrin) was subjected to oxidative attack from the radical generator (AAPH). To assess the antioxidative capacity of the cultures, diluted $(100 \times)$ aliquots of the samples and the buffer control were added to the reaction mixture, and the degree of protection against the oxidation of $\beta$-phycoerythrin was quantified by measuring the relative fluorescence emitted at $595 \mathrm{~nm}$ after excitation of the protein at $535 \mathrm{~nm}$ over a 70-min period (Glazer, 1990; Cao et al., 1995).

In this assay, total ORAC (Trolox equivalents) of a sample was directly proportional to the area under the kinetic curve of the plotted relative fluorescence values against time. To correct any deviation caused by instru- ment drifting, reagents, or any other assay conditions, the value of the analyzed samples was expressed with reference to known amounts and concentrations of Trolox and presented as Trolox equivalents (Cao et al., 1995).

All reactions were carried out in a Falcon 48-well plate (Becton Dickinson Labware; Becton Dickinson and Company, Franklin Lakes, NJ). To each well of the plate was first dispensed $20 \mu \mathrm{L}$ of the respective sample to be analyzed followed by $160 \mu \mathrm{L}$ of the working solution of $\beta$-phycoerythrin. Immediately before initiating the measurements, $20 \mu \mathrm{L}$ of AAPH were added to each well to initiate the reaction. The plate was covered and placed into the analyzer.

In the assay, the ability of compounds to protect $\beta$ phycoerythrin from oxidation was monitored by its decay curve. The quantification was achieved by determining the net protection area under the quenching curve of $\beta$-phycoerythrin in the presence of AAPH. The following equation was used to calculate the ORAC values (Cao et al., 1998):

$$
\text { ORAC value }=\text { X K }\left(\mathrm{S}_{\text {sample }}-\mathrm{S}_{\text {blank }}\right) /\left(\mathrm{S}_{\text {trolox }}-\mathrm{S}_{\text {blank }}\right)
$$

where $\mathrm{X}$ is the sample volume in microliters, $\mathrm{K}$ is the dilution coefficient, and $\mathrm{S}$ is the area under the curve of the corresponding subscript.

\section{Statistical Analyses}

For statistical analyses, the GLM procedures from SAS (1985) were used to determine whether there was any significant interaction between strains and treatments and whether any significant differences occurred among strains and treatments. Least squares means were used to separate the means.

\section{RESULTS}

\section{Reducing Activities}

Reducing activity of cultures grown in modified MRS. The reducing activities exhibited by the cultures when grown in modified MRS broth (without beef extract) supplemented with TTC are shown in Table 1. Based on results from preliminary experiments (data not shown), the cultures reached their maximum activity at 12 to $15 \mathrm{~h}$ of incubation. The statistical analysis of the results revealed no interaction for reducing activity between the strains and time. Thus, only the data for the 15-h incubation are shown. Lactobacillus delbrueckii ssp. lactis (RM2-5 and RM5-4), L. acidophilus (O16 and L-1), and L. casei (E10) exhibited the highest reducing activity in the respective species and among all analyzed cultures. These cultures also showed the 
Table 1. Reduction of 2,3,5-triphenyl tetrazolium chloride by cultures of lactobacilli during growth in MRS broth. ${ }^{1}$

\begin{tabular}{llll}
\hline Species & Strain & $\mathrm{pH}^{2}$ & $\mathrm{~A}_{485 \mathrm{~nm}}{ }^{2}$ \\
\hline Lactobacillus delbrueckii ssp. lactis & & & \\
& RM2-5 & 3.7 & $1.036^{\mathrm{A}}$ \\
& RM5-4 & 3.7 & $0.912^{\mathrm{AB}}$ \\
& RM6-5 & 3.6 & $0.819^{\mathrm{B}}$ \\
Lactobacillus acidophilus & & & \\
& O16 & 3.6 & $1.098^{\mathrm{A}}$ \\
& $\mathrm{L}-1$ & 3.6 & $1.000^{\mathrm{A}}$ \\
Lactobacillus delbrueckii ssp. bulgaricus & NCFM & 4.0 & $0.802^{\mathrm{B}}$ \\
& 18 & 6.3 & $0.338^{\mathrm{A}}$ \\
& 10442 & 6.4 & $0.045^{\mathrm{B}}$ \\
& $\mathrm{Y}-23$ & 6.4 & $0.019^{\mathrm{B}}$ \\
& & & \\
Lactobacillus casei & $\mathrm{E} 10$ & 3.7 & $1.104^{\mathrm{A}}$ \\
& 9018 & 4.3 & $0.688^{\mathrm{B}}$ \\
& $\mathrm{E} 5$ & 6.1 & $0.030^{\mathrm{C}}$ \\
\hline
\end{tabular}

A,B,C Numbers with the same superscripts within the same species are not different $(P>0.05)$.

${ }^{1}$ Following $15 \mathrm{~h}$ at $37^{\circ} \mathrm{C}$.

${ }^{2}$ Each value is an average of 3 replications.

highest production of acid as indicated by the $\mathrm{pH}$ reaching values well below $\mathrm{pH} 4.0$, indicating the degree of reduction was related to growth. None of the $L$. delbrueckii ssp. bulgaricus exhibited much reductase activity during the 15 -h incubation. The $\mathrm{pH}$ values for these strains exhibited minimal decrease during the incubation, indicating minimal growth.

\section{Antioxidative Capacity/Activity}

The same cultures used in the previous section (reducing activity) were studied for antioxidative activity. Their activities were assessed after growth in MRS broth for $18 \mathrm{~h}$ at $37^{\circ} \mathrm{C}$ using the ORAC method (Cao et al., 1995).

Antioxidative activity of cells grown in MRS broth. Washed cells of each culture were resuspended in potassium phosphate buffer and incubated at $37^{\circ} \mathrm{C}$ for $30 \mathrm{~min}$ to permit leakage of some intracellular antioxidant materials or for it to become dislodged from the cell surface. The supernatant was analyzed for antioxidative activity. Washed cells resuspended in buffer were sonicated, and the cell-free extracts were tested. The results of the antioxidative activity of both the whole cells and the cell-free extracts are presented in Table 2. The results are expressed as Trolox equivalents per $10^{9}$ cells. Both whole cells and cell-free extracts exhibited antioxidative capacity. For $L$. delbrueckii ssp. lactis RM5-4, L. acidophilus NCFM, L. delbrueckii ssp. bulgaricus (all strains), and L. casei 9018, cell-free extracts exhibited higher $(P<0.05)$ total antioxidative capacity than did the intact cells. In the remaining cases, although the total antioxidant capacity of the cell-free extracts was numerically higher, they were not statistically different $(P>0.05)$. Lactobacillius delbrueckii ssp. bulgarius (Y-23) exhibited by far the highest activities when compared with the remaining cultures. Values for L. delbrueckii ssp. lactis RM5-4, L. acidophilus L-1, L. delbrueckii ssp. bulgaricus Y-23, and $L$. casei 9018 and E5 were higher $(P<0.05)$ than other strains in their respective species.

The results from the TTC reductase tests were not indicative of the levels of antioxidant activity as measured by the ORAC assays for the cultures tested. Comparison of the data in Tables 1 and 2 shows no apparent relationship between relative intensities of reductase activity and amounts of antioxidant produced. Thus, the reductase activity was not useful in predicting the antioxidant activity of the cultures.

\section{DISCUSSION}

Tetrazolium chloride has been used in a number of studies to test cell viability or reductase activity (Laxminarayana and Iya, 1953; Eidus et al., 1959; Bhupathiraju et al., 1999). According to Seidler (1991), the water-soluble tetrazolium chloride is reduced to a waterinsoluble red compound (formazan), which is trapped inside the cell. In our study, the assessment of the reducing capacity of cultures of lactobacilli was made by growing the cultures in modified MRS broth supplemented with $0.5 \%$ TTC. The use of a suitable concentration of TTC was essential, as it can be suppressive (bacteriostatic influence) toward cell growth when in excess. The concentration used in the present study was well below the maximum (2\%) used by May et al. (1960), which caused no inhibition.

The cultures grown in MRS broth reached their maximum reducing activity between 12 and $15 \mathrm{~h}$. In most cases, reducing values between the 2 sampling periods did not show statistical difference. Lactobacillus delbrueckii ssp. lactis (RM2-5 and RM5-4), Lactobacillus acidophilus (O16 and L-1), and Lactobacillus casei (E10) exhibited the maximum reducing activities in the studied period. This result coincided with maximum growth for these cultures (data not shown), indicating that the degree of reduction for each culture was related to its growth.

The ORAC has been found to be a relatively simple, reliable, and sensitive method of quantifying the antioxidative capacity of foods and food products by protection of a protein from radical damage (Cao et al., 1993, 1995). In our study, the antioxidative activity of our cultures was assessed by quantifying the protection of $\beta$-phycoerythrin from attack by AAPH in the reaction mixture. Similar to other methods used for antioxidative assessment, the ORAC method gives the total anti- 
Table 2. Oxygen radical absorbance capacity ( $\mu \mathrm{mol}$ Trolox/L equivalents) of selected cultures of lactobacilli grown in MRS broth.

\begin{tabular}{|c|c|c|c|c|}
\hline \multirow[b]{2}{*}{ Species } & \multirow[b]{2}{*}{ Strain $^{1}$} & \multirow[b]{2}{*}{$\mathrm{cfu} / \mathrm{mL}^{1}$} & \multicolumn{2}{|c|}{ Trolox eq. $/ 10^{9}$ cells $^{2}$} \\
\hline & & & Cells $^{3}$ & $\begin{array}{l}\text { Cell-free } \\
\text { extract }^{4}\end{array}$ \\
\hline \multicolumn{5}{|c|}{ L. delbrueckii ssp. lactis } \\
\hline & RM2-5 & $6 \times 10^{8}$ & $507^{\mathrm{a}, \mathrm{AB}}$ & $790^{\mathrm{a}, \mathrm{B}}$ \\
\hline & RM6-5 & $8.7 \times 10^{8}$ & $304^{\mathrm{a}, \mathrm{B}}$ & $467^{\mathrm{a}, \mathrm{B}}$ \\
\hline & RM5-4 & $3.7 \times 10^{8}$ & $1082^{\mathrm{a}, \mathrm{A}}$ & $1758^{\mathrm{b}, \mathrm{A}}$ \\
\hline \multicolumn{5}{|c|}{ L. acidophilus } \\
\hline & O16 & $2.9 \times 10^{9}$ & $176^{\mathrm{a}, \mathrm{C}}$ & $212^{\mathrm{a}, \mathrm{C}}$ \\
\hline & NCFM & $1.1 \times 10^{9}$ & $411^{\mathrm{a}, \mathrm{B}}$ & $607^{\mathrm{b}, \mathrm{B}}$ \\
\hline & L-1 & $6 \times 10^{8}$ & $779^{\mathrm{a}, \mathrm{A}}$ & $936^{\mathrm{a}, \mathrm{A}}$ \\
\hline \multicolumn{5}{|c|}{ L. delbrueckii ssp. bulgaricus } \\
\hline & 18 & $1.8 \times 10^{8}$ & $474^{\mathrm{a}, \mathrm{B}}$ & $1817^{\mathrm{b}, \mathrm{B}}$ \\
\hline & 10442 & $6 \times 10^{8}$ & $127^{\mathrm{a}, \mathrm{B}}$ & $559^{\mathrm{b}, \mathrm{B}}$ \\
\hline & $\mathrm{Y}-23$ & $9 \times 10^{7}$ & $3152^{\mathrm{a}, \mathrm{A}}$ & $6070^{\mathrm{b}, \mathrm{A}}$ \\
\hline \multicolumn{5}{|l|}{ L. casei } \\
\hline & $\begin{array}{l}9018 \\
\text { E5 }\end{array}$ & $3.7 \times 10^{8}$ & $1113^{\mathrm{a}, \mathrm{A}}$ & $1365^{\mathrm{a}, \mathrm{A}}$ \\
\hline & E10 & $8.3 \times 10^{8}$ & $556^{\mathrm{a}, \mathrm{B}}$ & $676^{\mathrm{a}, \mathrm{B}}$ \\
\hline
\end{tabular}

${ }^{\mathrm{a}, \mathrm{b}}$ Means in the same row followed by the same lowercase superscript letter are not different $(P>0.05)$.

${ }_{\mathrm{A}, \mathrm{B}, \mathrm{C}}$ Numbers followed by the same uppercase superscripts in the same column within the same species are not different $(P>0.05)$.

${ }^{1}$ Cultures were grown in MRS; cfu/mL at $18 \mathrm{~h}$.

${ }^{2}$ Trolox eq. $/ 10^{9}$ cells $=\frac{\mu \mathrm{mol} \text { Trolox } / \mathrm{L} \text { equivalents } \times 10^{9}}{\mathrm{cfu} / \mathrm{mL}}$.

${ }^{3}$ Whole/intact washed cells; each value is an average of 3 replications.

${ }^{4}$ Each value is an average of 3 replications.

oxidative capacity of the analyzed sample rather than the capacity of the individual components of the system, but it also differs in some other aspects. It is the only method including the variables inhibition time and degree of inhibition in one system. It also allows the automated analysis of enormous number of samples at the same time and in a relatively short time period.

Various researchers have reported similar findings when working with whole cells and cell-free extracts of lactic acid bacteria but using different methods. Lin and Yen $(1999 a, b, c)$ reported that the cell-free extracts of all 19 cultures (L. acidophilus, L. delbrueckii ssp. bulgaricus, and Streptococcus thermophilus) included in their studies showed some degree of antioxidative activity when assessed by inhibition of ascorbate autoxidation. Lin and Chang (2000) reported that whole cells and cell-free extracts of L. acidophilus and Bifidobacterium longum exhibited some antioxidative capacity when tested using the thiobarbituric acid method. Based on the higher Trolox equivalents of the cell-free extracts compared with the intact cells observed in our study, it is possible that these cultures, once consumed, would release antioxidants into the gut after being exposed to bile salts. In related experiments (data not shown), we attempted to determine whether addition of bile salts to the cells would increase the release of antioxidants. However, the bile salts caused too much interference with the ORAC assay so that results were inconclusive.

The results of this study show that lactobacilli possess an antioxidative capacity that can be assessed quantitatively through their ability to protect $\beta$-phycoerythrin from radical oxidation. The greatest degree of antioxidant capacity was associated with the cellfree extracts of the cultures, which suggests that they may be important in delivering antioxidants to the intestines where they could be released when cells of the cultures encounter bile. Bile is known to alter the permeability of the organisms to enhance passage of substances into and out of the cells (Noh and Gilliland, 1993). Consumption of foods containing lactic acid bacteria may be encouraged and may also contribute to the health effects associated with dietary antioxidants.

\section{REFERENCES}

Bhupathiraju, V. K., M. Hernandez, D. Landfear, and L. AlvarezCohen. 1999. Application of tetrazolium dye as an indicator of viability in anaerobic bacteria. J. Microbiol. Methods 37:231-243.

Cao, G., H. M. Alessio, and R. G. Cutler. 1993. Oxygen-radical absorbance capacity assay for antioxidants. Free Radic. Biol. Med. 14:303-311.

Cao, G., and R. L. Prior. 1998. Comparison of different analytical methods for assessing total antioxidant capacity of human serum. Clin. Chem. 44:1309-1315.

Cao, G., S. L. Booth, J. A. Sadowski, and R. L. Prior. 1998. Increases in human plasma antioxidant capacity after consumption of con- 
trolled diets high in fruit and vegetables. Am. J. Clin. Nutr. 68:1081-1087.

Cao, G., C. P. Verdon, A. B. H. Wu, H. Wang, and R. L. Prior. 1995. Automated assay of oxygen radical absorbance capacity with the COBAS FARA II. Clin. Chem. 41:1738-1744.

Eidus, L., B. B. Diena, and L. Greenberg. 1959. Observations on the use of tetrazolium salts in the vital staining of bacteria. Can. J. Microbiol. 5:245-250.

Glazer, A. N. 1990. Phycoerythrin fluorescence-based assay for reactive oxygen species. Methods Enzymol. 186:161-168.

Halliwell, B., and S. Chirico. 1993. Lipid peroxidation: Its mechanism, measurement and significance. Am. J. Clin. Nutr. 57(Suppl):715S-725S.

Handelman, G. J., G. Cao, M. F. Walter, Z. D. Nightingale, G. L. Paul, R. L. Prior, and J. B. Blumberg. 1999. Antioxidant capacity of oat (Avena sativa L.) extracts. 1. Inhibition of low-density lipoprotein oxidation and oxygen radical. J. Agric. Food Chem. 47:4888-4893.

Knauf, H. J., R. F. Vogel, and W. P. Hammes. 1992. Cloning, sequencing, and phenotypic expression of katA, which encodes the calalase of Lactobacillus sake LTH667. Appl. Environ. Microbiol. 58:832-839.

Korpela, R., K. Peuhkuri, T. Lahteenmaki, E. Sievi, M. Saxelin, and H. Vapaatalo. 1997. Lactobacillus rhamnosus GG shows antioxidative properties in vascular endothelial cell culture. Milchwissenschaft 52:503-505.

Kullisar, T., M. Zilmer, M. Mikelsaar, T. Vikalemm, H. Annuk, C. Kairane, and A. Kilk. 2002. Two antioxidative lactobacilli strains as promising probiotics. Int. J. Food Microbiol. 72:215-224.

Laxminarayana, H., and K. K. Iya. 1953. Studies on the reduction of tetrazolium by lactic acid bacteria. Indian J. Dairy Sci. 6:75-91.

Laxminarayana, K., and K. K. Iya. 1954. Studies on the reduction of tetrazolium chloride by lactic acid bacteria. Part II. Oxidation reduction potentials in relation to dye reduction. Indian J. Dairy Sci. 8:32-38.

Lin, M.-Y., and F.-J. Chang. 2000. Antioxidative effect of intestinal bacteria Bifidobacterium longum ATCC 15708 and Lactobacillus acidophilus ATCC 4356. Dig. Dis. Sci. 45:1617-1622.

Lin, M.-Y., and C.-L. Yen. 1999a. Inhibition of lipid peroxidation by Lactobacillus acidophilus and Bifidobacterium longum. J. Agric. Food Chem. 47:3661-3664.

Lin, M.-Y., and C.-L. Yen. 1999b. Reactive oxygen species and lipid peroxidation product-scavenging ability of yogurt organisms. J. Dairy Sci. 82:1629-1634.

Lin, M.-Y., and C.-L. Yen. 1999c. Antioxidative ability of lactic acid bacteria. J. Agric. Food Chem. 47:1460-1466.

May, P. S., J. W. Winter, G. H. Fried, and W. Antopol. 1960. Effect of tetrazolium salts on selected bacterial species. Proc. Soc. Exp. Biol. Med. 69:364-365.

Noh, D. O., and S. E. Gilliland. 1993. Influence of bile on cellular intergrity and $\beta$-galactosidase activity of Lactobacillus acidophilus. J. Dairy Sci. 76:1253-1259.

Ouwehand, A. C., and S. J. Salminen. 1998. The health effects of cultured milk products with viable and non-viable bacteria. Int. Dairy J. 8:749-758.

SAS Institute. 1985. SAS Procedures Guide for Personal Computers, Version 6 Edition. SAS Inst., Inc., Cary, NC.

Seidler, E. 1991. Page 2 in The Tetrazolium-Formazan System: Design and Histochemistry. G. Fischer, ed. Verlag, Stuttgart, Germany.

Stecchini, M. L., M. Del Torre, and M. Munari. 2000. Determination of peroxy radical-scavenging of lactic acid bacteria. Int. J. Microbiol. 64:183-188.

Wang, H., G. Cao, and R. L. Prior. 1996. Total antioxidant capacity of fruits. J. Agric. Food Chem. 44:701-705.

Zaizu, H., M. Sasaki, H. Nakajima, and Y. Suzuki. 1993. Effect of antioxidative lactic acid bacteria on rats fed a diet deficient in vitamin E. J. Dairy Sci. 76:2493-2499. 